\title{
THE EU STRATEGY FOR THE DANUBE REGION AS AN INCLUSIVE FORM OF CROSS-BORDER ECONOMY
}

\author{
Yurii Maslov ${ }^{1}$
}

\begin{abstract}
The article considers the process of creation and features of activities of various types of transborder formations peculiar for the European Union. Today the cooperation within Euroregions becomes more and more widespread practice both in the EU and among the regions of countries-participants of the Union and those ones neighbouring to the EU, including Ukraine. The problem of modernization of the EU regional policy in the context of the intensification of globalization processes is touched upon. The influence of global factors and changes in the EU regional policy on the transformation of Ukrainian regional policy is determined. In the context of the development of the regional policy of Ukraine, problems of economic development and well-being of citizens in Ukrainian regions are identified; development directions for the cooperation of Ukraine and the EU in this area are established. The purpose of the article is to consider issues of cross-border economy, cross-border region, classify them, define features of Euroregion and, based on the analysis conducted, consider imperatives and problems related to the development and introduction of the Danube Strategy and identify the place and opportunities of Ukraine in this association. The macro-regional approach to solving the tasks of the integration policy of the European Union chosen by the European Union Committee allows uniting the territories according to the principle of their mutual supplementation, reducing the barriers of national borders and creating new opportunities for cross-border regions. The Danube Strategy, despite the common principles and methodologies for the formation of Euroregions, has obvious features. Firstly, the region is characterized by deep imbalances both between countries and within countries themselves. Secondly, the Strategy is an example of a multidisciplinary approach to territorial planning in the region and has a pronounced ecological character, and environmental problems are solved in the search for a compromise with the tasks of socio-economic development. Thirdly, being the internal strategy of the European Union, however, has a significant external dimension, the incorporation of which can be quite a challenge. There are four main directions for the regional development in the Danube Strategy (so-called "pillars": association, ecology, well-being, strengthening). For each direction, priority areas are designated that are supervised by the coordinating countries. Conceptually, the EUSDR is a continuation of the Europe-2020 strategic document of the EU and proclaims the achievement of the region of "smart, sustainable and inclusive development" as its main objectives. At the same time, a kind of paradox is that the Danube strategy aimed at levelling social, economic, institutional gaps in the region generates them by the very principles of its existence. It is hard to imagine that unequal countries, getting too different funding, will be able to equalize their capabilities at the finish. The strategy will help realize the EU's obvious desire to transform the Danube into an internal transport artery with a highly developed infrastructure and improved cargo traffic, which will allow connecting the North Sea with the Black and Azov seas, placing the transportation of resources of Caspian region and Asia under control of European structures. The creation and activity of cross-border regions make a significant contribution both to the strengthening of political and economic integration within the EU and to the development of cooperation between the member countries of the Union and neighbouring states.
\end{abstract}

Key words: European Union, cross-border associations, Euroregions, Danube region, integration, macro-regional approach.

JEL Classification: R11, R38, R50, L51, F60

\footnotetext{
Corresponding author:

${ }^{1}$ South Ukrainian National Pedagogical University named after K.D. Ushinsky, Ukraine.
} 


\section{Introduction}

At present, in Europe and in other parts of the world, the phenomenon of cross-border cooperation of regions is becoming increasingly popular. In practical terms, such cooperation is realized through the creation of cross-border associations of administrative-territorial units (regions) of various states. Regions of the EU countries have especially rich experience in this field due to both historical background and modern practice of political and economic integration.

Most researchers consider a cross-border region as a special limited space that unites administrativeterritorial units, communities or groups of people of different states that enter into different relationships with each other. There are also definitions, the reference point of which is the concept of cross-border cooperation.

The EU regional policy was formed and implemented under the influence of globalization factors, a complication of the interrelation of "regionalism globalism", transnationalization of the economy, features of the modern regionalization of the global market, formation of a new model of spatial architectonics of the world market.

The European Union, the result of these influences, as well as the European market, is an example of a regionalcentrist model of development, which initially united countries with developed market economies, gradually expanding the market and joining countries with medium and low levels of development. At the same time, the European Union is viewed as an experience of structuring transnational space (Malishevskiy N., 2016). This is due to the fact that in the last two decades in the European Union, two parallel processes took place: formal regionalization, within the framework of the administrative-territorial structure; informal regionalization, which is carried out as a result of the transformation of the global space, the formation of the poles of economic growth, the allocation of regional markets. As a result, three types of regional economic systems have emerged in the EU: a) formal, unified; b) functional (concentrated around the focal centre a large company, a shopping centre, a research centre); c) perceptual (determined by the human attitude to the territories) (Kodric, 2011).

The "Europe of the Regions" - "Europe of the Market" discussion ended with the adoption of theEU regional policy oriented towards administrative-territorial regionalization, promoting the socio-economic convergence of countries and regions, that is, equalizing territorial disparities by supporting non-competitive regions.

Its main areas were identified:

- promoting the restructuring and development of depressed areas (problem regions) (where thelevel of GDP per capita over the past 3 years is $<75 \%$ of the average Greece, Ireland, Eastern regions of Germany, etc.);
- providing financial assistance to regions where is stagnation of the industry (old industrial regions);

- combating long-term unemployment, support for employment initiatives;

- financing the development of agricultural areas and accelerating the restructuring of agriculture;

- assistance to underpopulated regions, where the population density is no more than 8 people per $1 \mathrm{sq} . \mathrm{km}$ (Sweden, Finland);

- reduction of differentiation in the levels of economic development of countries - new EU members (countries of Central and Eastern Europe).

To facilitate the statistical analysis of backward regions, the Unified Classification System was developed NUTS (Nomenclature of Territorial Units for Statistics). Regional policy is the second largest expense item in the EU budget after the Common Agricultural Policy and a no less significant area of activity for the European Union (Kuzmin, 2014).

\section{The methodology of research}

A number of works by foreign and domestic scholars are devoted to issues of regional development in the EU countries and Ukraine, in particular, Jacques Miller, D. Bil, G. Marcou, P. Hildreth, I. Hladii, V. Chuzhikov, N. Mikula, A. Mokii, O. Reut, M. Ombrembalskyi, M. Dolishnii, L. Prokopenko, and others. Despite consideration of the problems of the regions, the formation of regional policies in the EU and Ukraine, mega-regional contradictions within the framework of the common European economic space, the economic literature does not pay enough attention to assessing the challenges generated by modern processes in the global environment, diagnosing regional development risks in Ukraine, which actualizes the proposed topic for scientific inquiry.

The interaction of regional authorities with EU institutions and bodies is organized in different ways. It takes place indirectly and directly, during the planning and implementation of the EU regional policy - through the Committee of the Regions, during the Cohesion Forum held annually by the European Commission, in the framework of the activities of the Brussels offices of the regions. Established in 1994, the Committee of the Regions, a special advisory body consisting of representatives of local and regional authorities of member states, replaced the Advisory Board of regional and local authorities established by the European Commission in 1988, whose task was to advise on the formulation and implementation of regional policy. The Committee of the Regions, basing its activities on the principles of subsidiarity, maximum approximation to the interests and needs of EU citizens, as well as partnerships of different management levels in the process of making pan-European decisions, to a certain extent, coordinates work in the field of regional policy (Brinkhoff, Gabbe, Martinos, 2012). 
The change of institutional architectonics of the EU Regional Policy was influenced by the Treaty of Lisbon. The latter did not recognize the Committee of the Regions as one of the elements of the EU institutional mechanism. At the same time, the Committee was able to appeal to the Court of Justice of the European Union in order to protect its prerogatives in case of violation of the principle of subsidiarity (Communication from the Commission to the European Parliament, 2010).

Most researchers consider a cross-border region as a special limited space that unites administrativeterritorial units, communities or groups of people of different states that enter into different relationships with each other. There are also definitions, the reference point of which is the concept of cross-border cooperation. For example, the interpretation of M. Perkmann, who characterizes a cross-border region as a single territorial unit, consisting of areas whose authorities participate in cross-border cooperation programs (Perkmann, 2013).

Thus, a cross-border region is not only a space in the physical sense but also a social unit with its potential, formed on the basis of certain agreements. Formation of a cross-border region can rely on cultural or ethnic ties of adjacent territories, a common historical heritage or a community of interests (political and socio-economic). It is believed that the most cohesive transboundary regions are based on a combination of all three of the above factors.

In general, the formation of cross-border associations is based on the desire of neighbouring territories to achieve strategic partnership, resulting in the formation of relatively small regions, the level of integration in which may even exceed the degree of interdependence between the participating territories and other regions of the state to which they belong. Often, cross-border formations have not only their own government bodies but also a representative office in Brussels. The main goal of creating cross-border formations is the formation of a unified structure for coordinated problem solving and the achievement of tasks set by the participating regions. All transboundary associations can be very conditionally divided into two large groups, although they can vary considerably in their goals, competences, and capabilities.

The first group: Euroregions and similar structures. The Euroregion can be defined as a territory that includes border administrative divisions of at least two neighbouring countries, the area of the Euroregion is crossed by at least one state border. Researcher V. A. Shaliamin notes that "the Euroregion, on the one hand, can be defined as a geographically limited part of the border area, which is formed from territorialadministrative units on both sides of the border, united by common interests in developing the economy, protecting nature, preserving culture, and intensifying scientific exchanges. On the other hand, the Euroregion is a kind of umbrella project, within which bilateral and multilateral specific sectoral projects are implemented" (Merkulova, 2014).
Although these entities are not identical in legal status and organization, they have many common features: they operate on a permanent basis, and not temporarily for the implementation of certain projects; have a separate identity from the participants; have their own administrative, technical, and financial resources; have their own decision-making system; unite two or more administrative divisions that are parts of different states (besides, non-governmental organizations such as trade unions, chambers of commerce etc. also can participate); cooperate at the regional and not at the state level; have their own management bodies and structures; develop many areas of cooperation, where traditionally a lot of attention is paid not only to the economic aspect but also to socio-cultural issues (cooperation in health care, culture, science, environmental protection, etc.).

At the same time, depending on the wish of the founding parties, the Euroregion may or may not be a legal entity (Eurostat regional yearbook 2012).

The second group: Working communities. They are also permanent formations, however, unlike Euroregions, they do not have their own identity, their own decision-making process and powers separate from the powers of their members. They are largely dependent on the states, under the jurisdiction of which are the units belonging to the community. Compared to Euroregions, the range of tasks of working communities is significantly narrower: their activities are mainly focused on solving problems that are relevant for all participants and not related to the existence of a common border. The most common areas of cooperation are consultations, information sharing, and cultural projects (more rarely - economic cooperation). These structures unite a large number of member countries and large territories, while Euroregions have a small area of coverage (Brinkhoff, Gabbe, Martinos, 2012).

In practice, cross-border formations may include not only regional and local authorities but also chambers of commerce, regional business associations, and other interested organizations (Perkmann, 2013).

Cross-border formations can be attributed to a variety of political networks, which should meet the following conditions for the successful functioning and fulfilment of the tasks set.

Firstly, the presence of a "leader" - a person or structure that deals with all organizational issues, organizes necessary meetings and conferences, prepares an agenda, disseminates information about crossborder education activities, seeks support for projects by relevant government agencies and financial funds, attracts new participants, monitors the timely and accurate fulfilment of obligations by all members of the cross-border formation.

Secondly, the ability to benefit all interested parties is to create a situation where it is more beneficial for potential participants in a cross-border formation to participate in a cross-border project than not to participate in it. 
Thirdly, the ability to attract actors and resources - participation in any common project involves the investment by participants of one or another of their resources in the common cause. Very much depends on the willingness of interested parties to invest their resources.

Fourthly, limiting costs - participation in crossborder projects involves not only benefits but also certain costs, which are often proportional to the equity contribution. Coordinators of cross-border projects try to prevent the situation of a zero-sum game, as this can lead to frustration and the exit of the losing participants from the project. If the costs become too large for all participants, then the project ceases to exist.

Fifthly, enforcement of fulfilment of commitments the leadership of cross-border formations should be able to make the participants to clearly fulfil their commitments. This can be done through informal arrangements or by more formal means, such as concluding conventions, contracts, setting up a supervisory committee, etc. (Malishevskiy, 2016).

Speaking about the success criteria of a cross-border association, it is important to take into account not only the immediate result expressed in material achievements (economic benefits, building infrastructure, etc.) but also the effect of such actions as adjustment of cooperation mechanisms among the regions of different countries, organization of the communication process, developing an algorithm for solving problems and making joint decisions, creating conditions for the development of regional innovations, etc. It is necessary to take into account the reserve that is being created for the implementation of future projects in the framework of possibly other interregional groups (Martunyuk, 2015).

The attention of the supranational level to the crossborder regions increased with the development of the regional community policy. The reform of structural funds, the concepts of levelling and identifying the endogenous potential of the regions have led to the intensification of cross-border cooperation. Of course, this is not only the merit of the EEC but the growth of Euroregions stimulated financial support, and that in turn caused the growth of Euroregions in the territories mastered by the EU. The insufficiency and imperfections of the model of cross-border cooperation led to the emergence in 2006 of a new instrument for regulating cross-border cooperation in the context of European integration - the creation of the European Grouping for Territorial Cooperation - EGTC. This instrument of the regional policy of the European Union was created to "strengthen and create better conditions for cross-border cooperation” among EU countries (Malishevskiy, 2016).

The European Grouping for Territorial Cooperation (EGTC) is designed to complement the cross-national level of Euroregions and potential applicants. It was created as a stable legal structure with an autonomous legal personality that exists within the legal framework of member states, but the EGTC necessarily includes representatives of regional authorities, which contributes to the deepening of cross-border cooperation and creates conditions for building a more flexible management system. In the framework of current trends, this form is considered the most optimal form of interaction between the partner countries.

\section{Results and discussion}

The macro-regional approach to solving the problems of the integration policy of the European Union chosen by the EU Committee in Brussels allows uniting the territories according to the principle of their mutual supplementation, reducing the "barriers" of national borders and creating new opportunities for cross-border regions.

The European Union Strategy for the Danube Region (EUSDR) (Communication from the Commission to the European Parliament, 2010) became the second macro-regional strategy in the framework of the implementation of the EU regional policy, the model for which was launched in June 2009.

The Danube region is a functional area defined by its own river basin. Collaborating organizations, such as the Danube Commission and the International Commission for the Protection of the Danube River, deal with specific issues. The strategy extends this approach in order to set priorities in terms of integration. Geographically, this concerns primarily but not only: within the EU Germany (Baden-Württemberg and Bavaria), Austria, the Slovak Republic, the Czech Republic, Hungary, Slovenia, Romania, and Bulgaria, as well as beyond its borders - Croatia, Serbia, Bosnia and Herzegovina, Montenegro, the Republic of Moldova, and Ukraine (regions along the banks of the Danube). The strategy remains open to other partners in the region. Since the Danube flows into the Black Sea, it must undoubtedly be linked to the development prospects of the Black Sea region, which has a population of more than 100 million people and is the fifth largest territory of the EU (Eurostat regional yearbook, 2012).

The Danube macro-regional strategy, despite the common principles and methodologies for forming Euroregions, has obvious features. Firstly, the region is characterized by deep imbalances both between countries and within countries themselves. Secondly, the Strategy is an example of a multidisciplinary approach to territorial planning in the region and has a pronounced ecological character, and environmental problems are solved in the search for a compromise with the tasks of socio-economic development. Thirdly, being the internal strategy of the European Union, however, has a significant external dimension, the incorporation of which can be quite a challenge.

Four main directions for the regional development in the Danube Strategy are determined (so-called "pillars": association, ecology, well-being, strengthening). 
For each direction, priority areas are designated that are supervised by the coordinating countries. There are 11 such areas in total (Table 1). Projects selected to achieve the goals and objectives set within priority areas have leaders responsible for their implementation, in the person of countries, subregions, non-profit organizations, as well as private economic entities (Kodric, 2010).

Thus, the main directions of the Strategy are the idea of "smart, sustainable and inclusive development" of the Danube region based on the formation and implementation of promising areas of identified pillars.

The Danube macro-regional strategy is unique in that it implies the abandonment of the traditional model of development (through classical urbanization and industrialization of territories) and the transition to a more intensive format - through modernization, development, and introduction of technology innovations into existing capacities and infrastructure, as well as through improving the quality of human capital (the imperative of smart development). The main priorities include environmentally sound, not subject to the risks of natural and technogenic origin (the imperative of sustainable development), and the imperative of inclusive development is coordinated, cumulative development of all parties and aspects in the relationship and not at the expense of each other.

According to the stated goals and scope, the EU macro-regional strategy for the Danube region is an extremely large-scale project of Brussels. However, its implementation, in our opinion, will inevitably face a number of objectively arising challenges related to socio-economic and institutional imbalances.

The Danube region is characterized by serious heterogeneity. Within its borders, one can distinguish both highly developed urbanized and rich agricultural territories, as well as less developed and even depressed areas. It includes both countries-members of the
European Union and those that, to varying degrees, claim to receive this status, and non-members of this integration association. They have different political and economic traditions and peculiarities, which affect their ability to develop infrastructure, preserve the environment, and carry out socio-economic policy.

The countries with one of the highest standards of living in the EU and countries where the share of the population at risk of poverty or not integrated into the main society exceeds $40 \%$ are in the EUSDR field of action. In 2014 in Bulgaria, this figure was fixed at $49.1 \%$, in Romania $-40.3 \%$, on average in the EU this social group accounts for $24.2 \%$.

The majority of the population of Bulgaria (72.1\%), Hungary (70.7\%), Romania (89.5\%), Slovakia $(88.6 \%)$, Slovenia $(53.1 \%)$, Croatia $(62.2 \%)$, and the Czech Republic (72.0\%) lives in regions where GDP at purchasing power parity (PPP) per capita is less than $75 \%$ of the average regional GDP in $27 \mathrm{EU}$ countries, and for 85 out of 320 regions of the Danube Strategy, this figure will be below $50 \%$ of the average for the EU-27, and all of them are located in Bulgaria, Hungary, Romania, Slovakia, and Croatia (Eurostat regional yearbook 2016).

Particularly vividly, regional differences between the Danube countries are visible in the ratio of the productivity of the richest area in the region and the poorest (15.2:1). Thus, the level of GDP per capita of the capital of Bavaria, Munich, is $330.2 \%$, and the similar indicator of Bulgarian Silistra - 21.7\%.

Against the background of the average unemployment rate among the economically active population of $4.3 \%$ for Austria and 5.5\% for Germany in 2012, in Croatia and Slovakia it was 15.9 and $14.0 \%$, respectively, in Bulgaria - 12.3\%, Hungary - 10.9\% (Eurostat regional yearbook 2016).

The Stuttgart region of Baden-Württemberg has become the leader in the Danube region in terms of

Table 1

The main directions of the EU Strategy for the Danube Region

\begin{tabular}{|c|c|c|c|c|}
\hline Pillars & I. Association & II. Environmental protection & II. Building well-being & IV. Strengthening \\
\hline \multirow{4}{*}{ 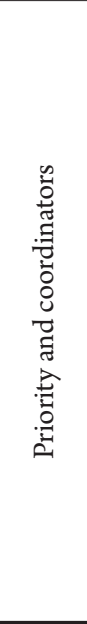 } & $\begin{array}{l}\text { improving mobility } \\
\text { and multimodality: } \\
\text { the development of inland } \\
\text { waterway transport } \\
\text { (Austria and Romania) } \\
\end{array}$ & $\begin{array}{l}\text { restoration and maintenance } \\
\text { of water quality } \\
\text { (Hungary, Slovakia) }\end{array}$ & $\begin{array}{l}\text { building a knowledge society } \\
\text { through the development } \\
\text { of science and education, } \\
\text { the introduction of information } \\
\text { technology (Slovakia, Serbia) }\end{array}$ & $\begin{array}{l}\text { building institutional capacity } \\
\text { and improving the quality } \\
\text { of cooperation } \\
\text { (Austria, Slovenia) }\end{array}$ \\
\hline & $\begin{array}{l}\text { development of road, rail, } \\
\text { and air transport } \\
\text { (Slovenia and Serbia) }\end{array}$ & $\begin{array}{l}\text { environmental risk } \\
\text { management } \\
\text { (Hungary, Romania) }\end{array}$ & $\begin{array}{l}\text { supporting the competitiveness } \\
\text { of entrepreneurship, including } \\
\text { cluster development } \\
\text { (Baden - Württemberg - } \\
\text { Germany, Croatia) }\end{array}$ & $\begin{array}{l}\text { cooperation in the interests } \\
\text { of security and the fight against } \\
\text { organized crime } \\
\text { (Germany, Bulgaria) }\end{array}$ \\
\hline & \begin{tabular}{|l} 
stimulating more \\
sustainable energy \\
(Hungary, Czech Republic) \\
\end{tabular} & \multirow{2}{*}{$\begin{array}{l}\text { conservation of the biological } \\
\text { diversity of the region, } \\
\text { landscapes, air and soil quality } \\
\text { (Bavaria - Germany, Croatia) }\end{array}$} & \multirow{2}{*}{$\begin{array}{l}\text { investing in the professional } \\
\text { skills of the population } \\
\text { of regions (Austria, Moldova) }\end{array}$} & \\
\hline & \begin{tabular}{|l|} 
support of culture and tourism, \\
contacts between people \\
(Bulgaria, Romania)
\end{tabular} & & & \\
\hline
\end{tabular}


expenditure on research and development, it allocates more than 5\% of GDP (5.83\%) for these purposes. In Karlsruhe and Tübingen of Baden-Württemberg, Upper Bavaria of Bavaria, as well as in Vienna and Austrian Styria, this figure exceeds 3\%. At the same time, in the former socialist countries of the Danube basin, the maximum level of $\mathrm{R} \& \mathrm{D}$ expenditure varies from $0.77 \%$ (South-West region of Bulgaria) to $2.47 \%$ (Central Bohemian Region in the Czech Republic), i.e. in most of them it is below the average for the European Union 2.01\% of GDP (Eurostat regional yearbook 2016).

The different status of Danube states in relation to membership in the European Union predetermines their unequal opportunities in obtaining financial resources for the implementation of their projects. EU structural funds money will be available for member countries. Only through the European Regional Development Fund (ERDF), the Cohesion Fund, the European Social Fund (ESF) in the period from 2007 to 2013 for the implementation of the tasks of the first pillar - development of transport, energy, and tourism - 34.5 billion euros were allocated. Funding for the second pillar programs related to environmental protection is estimated at 19.5 billion euros. 38.1 billion euros were allocated for the development of science, education, and information technologies, and 3.4 billion for the strengthening of security. The countries-neighbours of the European Union that belong to the Danube basin (Moldova and Ukraine) can only claim funds allocated under the European Neighbourhood Policy (ENP).

Another challenge to the success of the Danube Strategy is the unequal opportunities of participants in the field of management and administration. EU regional policy directly changes the territorial organization of the participating countries. It is aimed at activating new players of the regional policy in the face of the authorities of the subregional and local levels, NGOs, small and medium enterprises. However, such structures of civil society are well developed in countries with long-standing democratic traditions and federal structure, Austria and Germany, where they have the necessary legal powers, experience in conducting regional policy, and relevant institutions. The situation in the former socialist countries is somewhat different. The issue of harmonization of the national interests of the neighbouring member countries in the framework of the EUSDR is also problematic (Yurasova, 2013).

As a result of geopolitical changes of the last decade of the XX century, most of the Danube basin was in the European Union space, and the European Union got new opportunities to solve the problems existing in the region and more effectively realize its potential. By 2020, the association plans to increase its freight traffic on the Danube to 300 million tons per year. For comparison: all Ukrainian ports handled almost 146 million tons of cargo in 2016 (Yurasova, 2013).
In the Danube region, Ukraine is represented by four regions (Ivano-Frankivsk, Zakarpattia, Odesa, and Chernivtsi), with a population of about 6 million people. In 2016, the Government of Ukraine approved the State Program for the Development of Cross-Border Cooperation for 2016-2020, which identified priorities, tasks, activities, and 25 major projects for cross-border cooperation, almost half of which are aimed at solving the development priority tasks of the very Danube region.

The participation of Ukraine at the state level in the development of the Strategy from the very beginning was formal and declarative. As a result, Ukraine was not included in the list of states that are responsible for specific priority areas. For example, Romania - for activities in the following areas: increasing mobility and communication between different types of transport - water transport (with Austria, and Ukraine - only interested party), the development of culture and tourism, interpersonal contacts (together with Bulgaria), and environmental risk management (with Hungary).

At the same time, in spite of the competition existing between the states of the Danube basin, there are issues that cannot be resolved without joint efforts. Thus, the Danube Strategy in the field of transport development sets itself the following goals:

- to increase the volume of transportation of goods by $20 \%$ until 2020 compared with 2010;

- to eliminate the existing navigation "narrowing" on the river in order to ensure navigation of VIb-type ships throughout the year by 2020 ;

- to improve the travel time of competitive passenger traffic between the main cities;

- to develop effective multimodal terminals in the ports of the Danube in order to link inland waterways with rail and road transport by 2020.

Now the share of Danube shipping in the total volume of traffic on inland waterways in Europe is about 10\%, which creates an idea of its significant reserves. This reserve really exists. However, the transportation market is under constant pressure from various factors, in particular, the global financial and economic crisis. In addition, the Danube shipping route often does not compete with rail and road transport. According to experts, the main reason for the traditional weakness of the Danube shipping market is the underdeveloped infrastructure and the uneven development of its individual elements. It is this factor that inhibits the introduction on the Danube of new, above all high-speed, transportation technologies that could compete with the railways and highways in terms of time and cost.

The tasks assigned require serious financial resources and, in technical terms, efficient design solutions. Given the limited financial resources of each of the nation states, the goal can be achieved only through joint efforts.

The financing agreement for the Danube Transnational Program was signed by Ukraine in December 2017. The law on ratification of financing was signed by the President of Ukraine only in October 2018. 
The implementation of the agreement will contribute to the fulfilment of the obligations defined by the Association Agreement between Ukraine and the European Union, as well as the socio-economic development of the Ukrainian part of the Danube region, which covers the Odesa, Ivano-Frankivsk, Chernivtsi, and Zakarpattia regions. The program is one of the financial instruments of the European Union for the implementation of the EU Strategy for the Danube Region, participation in which opens for Ukrainian partners the opportunity to receive funding and implement projects together with partners from European countries of the Danube Region.

Under this program, the European Union and Hungary will provide Ukraine with a donation of 5 million euros for projects that will be selected on a competitive basis according to its rules. Funding is expected in four areas: "Innovation and social responsibility", "Environment and cultural responsibility", "Improving infrastructure links and energy efficiency", "Good governance in the Danube Region". The implementation of the projects will strengthen interregional and cross-border cooperation and partnership in the areas of development of transport infrastructure, energy, entrepreneurship, communication networks, culture, education, tourism, healthcare, etc.

In our opinion, one of the most powerful latent reserves for the development of economic cooperation in the Danube Strategy is the use of the ethnic potential of diasporas living in Ukraine. For shaping a sustainable economic design strategy, the use of the possibilities of ethnic identity can lead to the formation of loyal conditions due to the use of the transparent possibilities of diasporas. The following major diasporas live on the territory of Ukraine: Bulgarian (about 204.7 thousand, mainly in the Odesa region - 150.6 thousand people and Zaporizhzhia region - 27.4 thousand); Romanian (about 151.1 thousand people); Hungarian (about 120 thousand, but recently its number is rapidly decreasing). Engaging diasporas as ethnocultural communities with collective interests and goals can contribute to the development of a strategy at the national, regional, and local levels. The formation of informational interaction between diasporas and relevant national-cultural associations with the authorities, local self-government, and other public organizations and movements will help to create unique tools for resolving issues of ethno-social, ethno-political, and ethno-conflict policies.

\section{Conclusions}

The creation and activity of cross-border regions make a significant contribution both to the strengthening of political and economic integration within the EU and to the development of cooperation between the member countries of the Union and neighbouring states.
Speaking about the results of cross-border formations, it is worth paying attention to a certain negative potential. The activity of cross-border regions, especially Euroregions with a high degree of integration, can contribute to the development of separatist tendencies at the level of national states since the radical regional authorities have access to an alternative agency to the state, through which they have the opportunity to realize their economic and political interests.

Cooperation between Ukraine and the EU in the field of regional policy today focuses on the following areas: 1) implementation of the Memorandum of Understanding to establish a dialogue in the field of regional policy; 2) the establishment of interaction between representatives of local and regional authorities of Ukraine and the EU in the framework of the Committee of the Regions of the EU; 3) participation in the implementation of the Eastern Partnership Pilot Regional Development Program; 4) implementation of projects at the regional level taking into account EU financial instruments (European Neighbourhood and Partnership Instrument, European Investment Bank, Neighbourhood Investment Facility); 5) Ukraine's involvement in the implementation of the EU Strategy for the Danube Region; 6) facilitating the involvement of Ukrainian regions in the activities of European regional associations, in particular, the Assembly of European Regions, the Association of European Border Regions, the Council of European Municipalities and Regions, the Conference of Peripheral Maritime Regions, the Conference of Presidents of Regions with Legislative Powers.

Conceptually, the EUSDR is a continuation of the Europe-2020 strategic document of the EU and proclaims the achievement of the region's "smart, sustainable and inclusive development" as its main objectives. At the same time, a kind of paradox is that the Danube strategy aimed at levelling social, economic, institutional gaps in the region generates them by the very principles of its existence. It is hard to imagine that unequal countries, getting too different funding, will be able to equalize their capabilities at the finish.

An attempt to eliminate the disparities in the region may lead to their strengthening and consolidation; more developed countries will go forward. The initiators of EUSDR do not conceal that one of the goals of the Strategy is to create a "water-transporting European Union". This implies the unification of the Danube and Rhein navigation. However, given the weak technical equipment of most of today's ships belonging to the countries of Southeast Europe and the obvious advantages of the Rhine shipowners, this will most likely lead to the bankruptcy of some Danube shipping companies (including, for example, Ukrainian) and the next assertion of Western European domination on the Danube. In addition, the EU Strategy for the Danube Region aims to ensure that technical, navigation, legal, and environmental regulations on navigation on 
the Danube, as well as to unify and harmonize radio communication standards with the standards adopted in the EU. Obviously, all this may hinder the navigation activities of other participants remaining outside the framework of the Strategy.

Of all the aspects of the development of the Danube region which have been updated by the EUSDR, in our opinion, the most problematic is the innovation sphere. Disproportions in this area seem overwhelming. Especially since interstate cooperation between leading and catching-up countries is determined as the main approach to solving the problem and involves the use of the first available new technologies. In other words, it all comes down to the banal transfer of scientific developments already developed in the West to more backward players in the region, which will be presented as a process of their modernization. A platform for the emergence and implementation of these innovations will still remain more advanced regions.

Despite the significant external component, it should be recognized that the EUSDR is an internal EU strategy aimed at solving the internal problems of the association. The entire decision-making process is concentrated within European institutions; coordination at the political level remains the prerogative of the European Commission. The high-level group is represented by EU member states, non-member countries will be invited to its meetings only in some cases.

A differentiated European approach consists in preference to individual EU members and the entire Community, although they may not be beneficial in their consequences for neighbouring countries. The Danube macro-regional strategy will help to realize the EU's obvious desire to turn the Danube into an internal transport artery with a highly developed infrastructure and improved cargo traffic, which will allow connecting the North Sea with the Black and
Azov seas, placing the Caspian and Asian resources transportation under control of European structures.

In addition, the EUSDR can be viewed as a mechanism for implementing some of the objectives of the Eastern Partnership Program - the integration of the neighbouring countries into the EU's influence through the harmonization of national legislation and legal norms in the field of trade liberalization, transport services for inland water transport, technical, navigation, and environmental rules for shipping on the Danube with European ones.

Summarizing the above, it should be emphasized that the main challenge for the EUSDR remains the excessive heterogeneity of the Danube macro-region. Despite the considerable financial resources allocated for the implementation of integration policy objectives, the era of consolidation in the EU will not come soon, because the mechanisms used, including the macroregional approach, if not aggravate, then certainly fix the gap between the leaders and the laggards.

As a part of the deepening of integration processes, the use of the potential of Euroregions requires special attention (today, 8 Euroregions have been created on the territory of Ukraine) and the intensification of cross-border cooperation. Despite the vast European experience, the development of many models of the functioning of this institution in Ukraine, the implementation of cross-border projects has not received sufficient development. The creation of the Carpathian, Bug, and Lower Danube Euroregions, which could play an important role in blurring the borders with the European Union, does not have a proper legislative base. When introducing the European model in Ukraine, the "policy of intentions" dominates in interregional policy, while the experience of cooperation and introduction of joint projects is so low that it gives some researchers ground to talk about the inefficiency of the Euroregions.

\section{References:}

Brinkhoff, A., Gabbe, J., Martinos, H. (2012). Institutional aspects of cross-border cooperation. Retrieved from: http://www.aebr.net/publikationen/pdfs/inst_asp_99.en.pdf

Communication from the Commission to the European Parliament (2010). Communication from the Commission to the European Parliament the Council, the European Economic and Social Committee and the Committee of the Regions. European Union Strategy for Danube Region: Brussels, 2010. Retrieved from: http://eur-lex.europa.eu/ LexUriServ/LexUriServdo?uri=CELEX:52010DC0715

Communication from the Commission to the European Parliament, the Council (2009). Communication from the Commission to the European Parliament, the Council, the European Economic and Social Committee and the Committee of the Regions concerning the European Union Strategy for the Baltic Sea Region. Brussels, 2009. Retrieved from: http://eur-lex.europa.eu/LexUriServ/LexUriServ.do?uri=CELEX:52009DC0248:EN:N0T

Eurostat regional yearbook 2016. Eurostat: website. Retrieved from: http://epp.eurostat.ec.europa.eu/cache/ ITY OFFPUB/KS-HA-12-001/EN/KS-HA-12-001-EN

Kochubej, N. V., Kochubej, R. V. (2005). Sinergeticheskaja metodologija issledovanija socialno-ekonomicheskih sistem [Synergistic research methodology of socio-economic systems]. Socialno-jekonomicheskie problemy informacionnogo obshhestva. L. G. Melnik (Ed). Sumy: Universitetskaja kniga. (in Ukrainian)

Kodric, M. (2011). The EU Strategy for the Danube Region: What Potential Contribution to Regional Stability and Cooperation: Bruges Regional Integration \& Global Governance Papers. Retrieved from: http:/ /www.cris.unu.edu/ filead-min/workingpapers/BRIGG_papers/BRIGG_4_2011.pdf 
Kuzmin, V. M. (2014). Transgranichnoye sotrudnichestvo Rossii i Yevropeyskogo Soyuza v formate yevroregionov na Severe Yevropy i regione Baltiyskogo morya v svete novoy programmy territorialnogo sotrudnichestva «Obyektiv 3» [Cross-border cooperation between Russia and the European Union in the format of Euroregions in the North of Europe and the Baltic Sea region in the light of the new program of territorial cooperation "Objective 3"]. Retrieved from: http://convention2008.risa.ru/paper/download/251/1/

Malishevskiy, N. (2016). Yevropeyskiy soyuz regionov: realnost ili utopiya? [European Union of Regions: Reality or Utopia?]. Retrieved from: http://www.belarustime.ru/information/opinion/bc24523edec2ff5d.html

Martunyuk, O. (2015). Actual forms of agrarian business organizing under contemporary conditions. Scientific Economic journal. «Actual Problems of Economics» Actual, 8(170), 188-193.

Merkulova, E. A. (2014). Metodicheskij instrumentarij vyjavlenija tochek jekonomicheskogo rosta $\mathrm{v}$ regione [Methodical toolkit to identify points of economic growth in the region]. Socialno-jekonomicheskie javlenija i process Socio-economic phenomena and processes, 10 (9). Retrieved from: http:// cyberleninka.ru/article/n/metodicheskiyinstrumentariy-vyyavleniya-tochek-ekonomicheskogo-rosta-v-regione (in Russian)

People at risk of poverty or social exclusion by age and sex. Eurostat: 13.03.2013. Retrieved from: http://appsso.eurostat.ec.europa.eu/nui/show. do?dataset=ilc_peps01\&lang=en (Access date: 15.04.2013)

Perkmann, M. (2013). Cross-border regions in Europe. Significance and drives of cross-border cooperation. Retrieved from: http://spiral.imperial.ac.uk/bitstream/10044/1/1407/1/Perkmann\%20european\%20urban\%20 regional\%20studies\%202003\%20cross-border\%20 regions.pdf

Regional Cohesion and competition in the age of globalization (2000). Cheltenham: Edward Elgar Publishing Limited.

Yurasova, L. A. (2013). Yevropeyskaya strategiya razvitiya dunayskogo regiona: problemy i perspektivy [European strategy for the development of the Danube region: problems and prospects]. Problemy natsionalnoy strategii, 4(19). Retrieved from: https://riss.ru/images/pdf/journal/2013/4/05.pdf 